\title{
Variation in the $\beta$-tubulin isotype 1 gene at codon 167 and 200 responsible for benzimidazole resistance in Haemonchus contortus in sheep of Krishna District, AP, India
}

\author{
Kaplaywar Sathish, Chennuru Sreedevi, Krovvidi Sudhakar*, \\ Pattipati Malakondaiah, and G. S. Rao \\ Department of Veterinary Parasitology, NTR College of Veterinary Science, Sri Venkateswara Veterinary \\ University, Gannavaram, Andhra Pradesh, India
}

\begin{abstract}
SATHISH, K., C. SREEDEVI, K. SUDHAKAR, P. MALAKONDAIAH, G. S. RAO: Variation in the $\beta$-tubulin isotype 1 gene at codon 167 and 200 responsible for benzimidazole resistance in Haemonchus contortus in sheep of Krishna District, AP, India. Vet. arhiv 88, 323-333, 2018.
\end{abstract}

\section{ABSTRACT}

A study was carried out for detection of single nucleotide polymorphisms at codon 167 and 200 of the $\beta$-tubulin isotype 1 gene that are linked to BZ resistance of Haemonchus contortus in sheep. A total of 226 adult male worms were genotyped from different regions of Krishna district, Andhra Pradesh. Amplification of DNA from each worm by PCR, followed by semi-nested PCR, yielded an expected fragment of 488 bp product. The PCR product was subsequently digested with restriction endonuclease SnaBI and TaaI to detect mutation at codon 167 and 200 respectively. On digestion, three different fragment patterns were observed at codon 200, one with 215 bp, 206 bp and 67 bp (homozygous resistant; 'rr'), the second with 282 bp, 215 bp, 206 bp and 67 bp (heterozygous; 'rS'), and another with 282 bp and 206 bp fragment (homozygous susceptible; 'SS'). No resistance allele (TAC) was evident at codon 167 in any worms including the worms that carried a susceptible allele (TTC) at codon 200. The overall genotype frequencies varied significantly $(\mathrm{P}<0.01)$ with respect to the $\beta$-tubulin gene/TaaI locus in the study area. The frequency of ' $r S$ ' $(64.60 \%)$ genotypes was high compared to that of 'rr' and 'SS' genotypes. The genotype frequency for ' $r r$ ' worms ranged from $6.25 \%$ to $31.82 \%$ among different regions. In general, the prevalence of $\mathrm{BZ}$ resistance allele was found to be significantly $(\mathrm{P}<0.01)$ higher (54.0\%). Results revealed $\beta$-tubulin isotype 1 polymorphism at codon 200 in $H$. contortus of sheep indicating the occurrence of resistance allele in the study area.

Key words: Haemonchus contortus; benzimidazole resistance; $\beta$-tubulin gene polymorphism; PCR-RFLP

\footnotetext{
*Corresponding author:

Assist. Prof. Dr. Krovvidi Sudhakar, PhD, Dept. of Animal Genetics and Breeding, NTR College of Veterinary Science, Gannavaram-Andhra Pradesh, India, Phone: +91 944008 7461; E-mail: vetsreesudha@rediffmail.com
} 


\section{Introduction}

Resistance to anthelmintics in gastrointestinal nematodes represents a major threat to sheep management and production. Haemonchus contortus is one of the pathogenic blood sucking nematode in small ruminants, and the major approach to control the rate of infection in endemic regions globally depends on chemotherapy using benzimidazoles (BZ). It is evident that BZ binds to $\beta$-tubulin and interferes with the polymerization of microtubules there by destabilizing the intracellular environment in the parasite. Frequent use of BZ for decades has forced the selection and emergence of BZ resistant $H$. contortus populations in several areas of the world. Genetic studies on BZ resistance by LE JAMBRE (1985) revealed that more than one genetic locus is involved in BZ resistance in $H$. contortus. One of the genetic mechanisms conferring resistance in field populations of $H$. contortus is a change of TTC to TAC at codon 200 (F200Y) of the $\beta$-tubulin isotype 1 gene (ELARD et al., 1999) which has been frequently reported. A similar polymorphism (TTC to TAC) at codon 167 (F167Y) is acknowledged to be involved in BZ resistance in $H$. contortus, but no simultaneous substitutions at two codons 167 and 200 have been observed in the same allelic sequence of $H$. contortus of small ruminants, so they are thought to be mutually exclusive (SILVESTRE and CABARET, 2002).

A clear appraisal of the resistance or susceptibility of the target worms is required for effective control strategies and also to maintain the efficacy of the currently available anthelmintics wherever resistance has not emerged. This is only possible if sufficient means are available for the diagnosis of anthelmintic resistance at an early stage. Conventional methods, viz. the faecal egg count reduction test (FERT), egg hatch assay (EHA) and larval development assay (LDA) can only help to detect resistance when 25 per cent of the individuals in the population are already resistant (MARTIN et al., 1989), and these tests are not economical. In contrast, PCR based assays can detect resistance at the initial stage, even when only one per cent of the resistant parasites are in the population (SILVESTRE and HUMBERT, 2000), and these assays are very useful in perception of the $\mathrm{BZ}$ resistance mechanism.

In India, the occurrence of BZ resistance in $H$. contortus has been reported in different sheep populations since 1976 by conventional (VARSHNEY and SINGH, 1976) and molecular techniques (TIWARI et al., 2006; KAUSHIK et al., 2016). Among the molecular assays, PCR-RFLP has been found to be an economically viable genotyping assay and to detect the SNP's at codon 167 and 200 of the $\beta$-tubulin isotype 1 gene of $H$. contortus (SHOKRANI et al., 2012). Owing to this and due to the lack of reports on BZ resistance in sheep from Andhra Pradesh, an attempt was made for the first time to investigate the resistance status of $H$. contortus in sheep populations in Krishna district, Andhra Pradesh, India. 


\section{Materials and methods}

Collection of parasites (Haemonchus contortus): Adult male Haemonchus contortus worms were collected directly from the abomasum of various sheep brought to the local abattoirs in Krishna district, Andhra Pradesh. In order to have a representative sample of $H$. contortus worms from all the Animal Husbandry divisions of the district, a Random Stratified sampling method was used to select the areas, and the worms were collected from the Vijayawada (31), Gannavaram (60), Hanuman Junction (31), Ibrahimpatnam (32), Nuziveedu (23), Gudiwada (22) and Machilipatnam (27) regions (Fig. 1). A total of 226 parasites were collected and preserved in $70 \%$ alcohol at $-20{ }^{\circ} \mathrm{C}$ until use, after washing in PBS (pH 7.4).

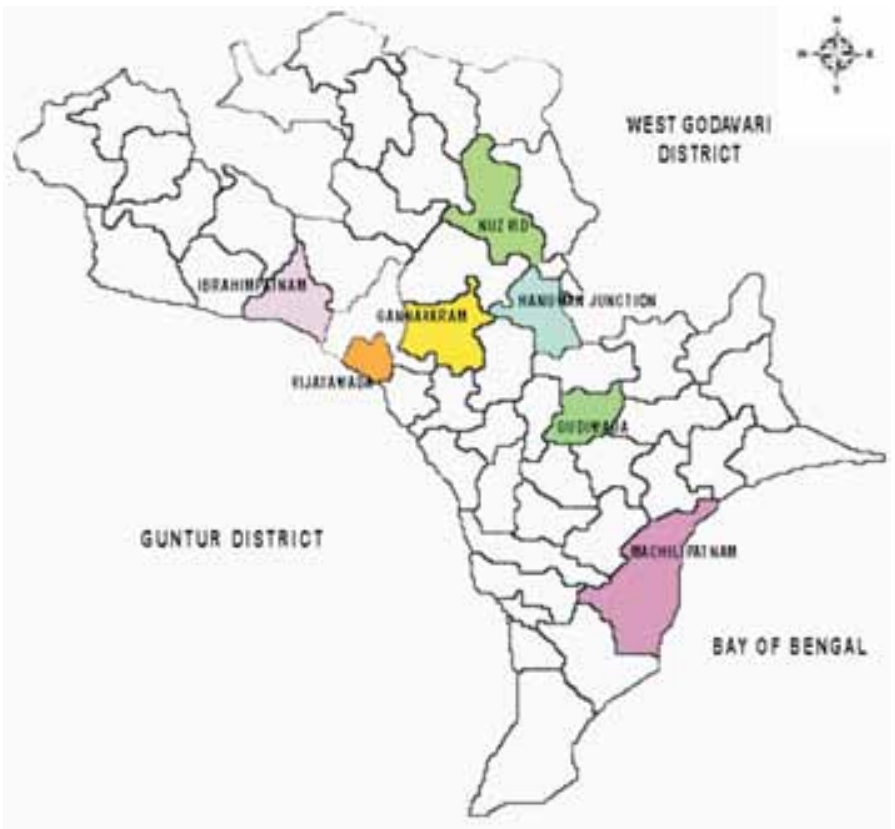

Fig. 1. Location map of sampling areas

Genotyping of $\beta$-tubulin gene by polymerase chain reaction (PCR) / RFLP

DNA extraction. The genomic DNA was isolated from each adult male $H$. contortus worm using the protocol explained by TIWARI et al. (2006), with minor modifications. Each individual $H$. contortus worm was digested in a digestion mixture comprised of $195 \mu \mathrm{L}$ of lysis buffer (10 mM TrisHcl, 0.1 M EDTA, 2.0 per cent SDS, distilled water) and $10 \mu \mathrm{L}$ Proteinase-k $(20 \mathrm{mg} / \mathrm{mL})$, at $37{ }^{\circ} \mathrm{C}$ for 4 hours. After incubation, $200 \mu \mathrm{L}$ of 
phenol:chloroform:iso-amyl alcohol (25:24:1) was added, mixed and centrifuged at 12000 $\mathrm{rpm}$ for 5 minutes. The aqueous phase was transferred to a fresh $2 \mathrm{~mL}$ micro centrifuge tube. Finally, the DNA was precipitated by absolute isopropanol at $12000 \mathrm{rpm}$ and the precipitated DNA was again dissolved in an equal volume of $70 \%$ alcohol and centrifuged at $13000 \mathrm{rpm}$ to recover the DNA pellet. The dried DNA pellet was resuspended in $30 \mu \mathrm{L}$ of nuclease free water and stored at $-20{ }^{\circ} \mathrm{C}$ until further use.

Oligonucleotide primers. The forward (5'-GGTTGTGATTGCCTTCAGGT-3') and reverse (5'- GATCAGCATTCAGCTGTCCA-3') primers were custom designed for amplification of the $\beta$-tubulin isotype 1 gene of $H$. contortus, capturing the mutation site on the basis of the sequence available from the NCBI (GenBank Accession No. X80046.1). UT-HC167 MF-primer (modified forward primer) was adopted from already published primers (SHOKRANI et al., 2012) for semi-nested PCR. Primers were diluted in nuclease and protease free water to give a final concentration of $10 \mathrm{pmoles} / \mu \mathrm{L}$.

PCR amplification and RFLP of the $\beta$-tubulin gene. Amplification of the $\beta$-tubulin isotype 1 gene from the genomic DNA of each worm was carried out in a Prima-Duo Thermal cycler (Himedia, India) in a final reaction volume of $15 \mu \mathrm{L}$, using the forward and reverse primers. Volumes of $80 \mathrm{ng}$ of extracted DNA sample and 10 pmoles of each forward and reverse primer were added to the mastermix. The mastermix (Eppendorf) for PCR reactions was with a final concentration of magnesium $1.5 \mathrm{mM}$, dNTPs $200 \mu \mathrm{M}$ and Taq polymerase $1.25 \mathrm{U}$. Amplification was performed with a program of $3 \mathrm{~min}$ at 94 ${ }^{\circ} \mathrm{C}$ followed by 35 cycles at $94{ }^{\circ} \mathrm{C}$ for $30 \mathrm{~s}, 60^{\circ} \mathrm{C}$ for $30 \mathrm{~s}$ and $72{ }^{\circ} \mathrm{C}$ for $45 \mathrm{~s}$ and a final elongation step at $72{ }^{\circ} \mathrm{C}$ for $5 \mathrm{~min}$. Semi-nested PCR was performed on the diluted (1:20) PCR product with UT-HC167 MF-primer, as per the protocol explained by SHOKRANI et al. (2012). Five microliters of PCR amplicons were analyzed on ethidium bromide stained $2 \%$ agarose gel, and the sizes and quantities of the PCR products were verified by comparison with a quantitative ladder.

The PCR products generated were digested separately with TaaI (Thermoscientific) for recognition of the nucleotide sequences 5'-ACNGT-3' at codon 200, and with SnaBI (Thermoscientific) for recognition of the nucleotide sequences 5'-TACGTA-3' at codon 167 . The reaction was accomplished by digestion at $65^{\circ} \mathrm{C}$ and $37^{\circ} \mathrm{C}$ overnight for TaaI and SnaBI enzymes respectively. To control enzyme activity, the semi-nested PCR product without a restriction enzyme was used as a positive control, and a mix inoculated with ultrapure water in a substitution of PCR product and enzyme was used as a negative control. Digested products were separated on a $2.0 \%$ agarose gel to observe the polymorphic patterns and thus the genotypes of the $\beta$-tubulin gene of $H$. contortus.

Statistical analysis. The genotypes were detected by observing the RFLP pattern of each sample in agarose gels for the $\beta$-tubulin gene. The allele frequencies of each allele were calculated separately for the different codons 167 and 200. Genotype and allele frequencies were calculated as per FALCONER and MACKAY (2009). The chi-square 
test of goodness of fit was carried out with the observed and the expected numbers to check whether the worm population was in Hardy - Weinberg equilibrium. F- statistics (WEIR and COKERHAM, 1984) were estimated for analysis of the population structure of the parasite with respect to their resistance to $\mathrm{BZ}$.

\section{Results}

Amplification the $\beta$-tubulin isotype 1 gene. A total of 226 worms were genotyped for detection of point mutations in the $\beta$-tubulin isotype 1 gene of $H$. contortus. Amplification of DNA from each worm yielded the expected fragment of 629 bp product in primary PCR. Semi-nested PCR resulted an expected fragment of 488 bp product, which was used for further analysis. Oligonucleotide primers did not yield PCR product with the negative control.

The $\beta$-tubulin isotype 1 gene/TaaI polymorphism in $H$. contortus in sheep. On digestion of the PCR product with restriction endonuclease TaaI three different patterns were observed at codon 200, one with $215 \mathrm{bp}, 206 \mathrm{bp}$ and $67 \mathrm{bp}$, the second with 282 bp, $215 \mathrm{bp}, 206 \mathrm{bp}$ and $67 \mathrm{bp}$, and the third with $282 \mathrm{bp}$ and $206 \mathrm{bp}$ fragment (Fig. 2) which were referred to 'rr' (homozygous resistant; TAC/TAC), 'rS' (heterozygous; TAC/TTC) and 'SS' (homozygous susceptible; TTC/TTC) genotypes, respectively. In 'rs' and 'rr' patterns, by virtue of the very few base pair differences between the 215 and $206 \mathrm{bp}$ bands, they were not wide enough apart to be appreciated as different bands on visualization with gel electrophoresis. These 215 and 206 bp bands (Fig. 2 lane: 4-8) can be differentiated from 206 bp (Fig. 2, lane: 1-3) with respect to intensity and the presence of an additional $282 \mathrm{bp}$ band in 'rs' genotypes.

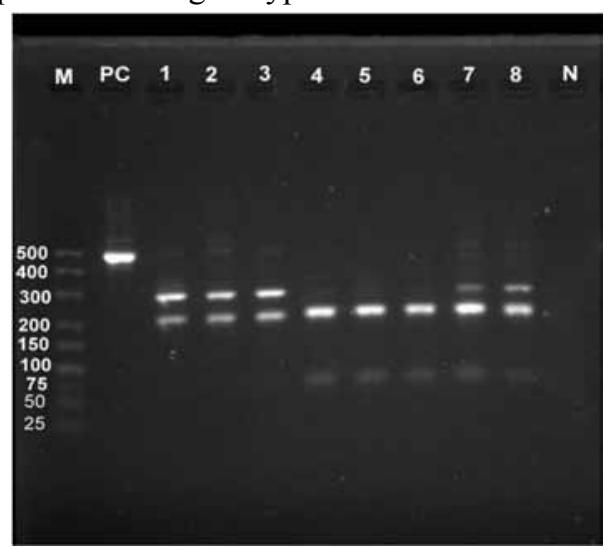

Fig. 2. RFLP Pattern of ß-tubulin isotype1 gene/Taa1 in H. contortus. M: 25 bp ladder, PC:

Positive control, N: Negative control, Lane 1-3: SS (Susceptible), Lane 4-6: rr (Homozygous resistant), Lane 7-8: rS (Heterozygous). 
K. Sathish et al.: Variation in $\beta$-tubulin gene at codon 167 and 200 of Haemonchus contortus

Table 1. Genotypic and allelic frequencies of benzimidazole resistance in adult $H$. contortus from different regions of Krishna district, Andhra Pradesh

\begin{tabular}{|l|c|c|c|c|c|c|}
\hline \multirow{2}{*}{ Region } & \multicolumn{3}{|c|}{ Genotypic frequency } & & \multicolumn{2}{c|}{ Allele frequency } \\
\cline { 2 - 4 } & $\begin{array}{c}\text { Homozygous } \\
\text { resistant (rr) }\end{array}$ & $\begin{array}{c}\text { Heterozygous } \\
\text { (rS) }\end{array}$ & $\begin{array}{c}\text { Homozygous } \\
\text { susceptible (SS) }\end{array}$ & $\begin{array}{c}\chi^{2} \\
\text { value }\end{array}$ & $\begin{array}{c}\text { Resistant } \\
(\mathrm{r})\end{array}$ & $\begin{array}{c}\text { Susceptible } \\
(\mathrm{S})\end{array}$ \\
\hline Ibrahimpatnam** & $6.25(2)$ & $75.0(24)$ & $18.75(6)$ & 8.7 & 0.44 & 0.56 \\
\hline Vijayawada** & $12.9(4)$ & $77.42(24)$ & $9.68(3)$ & 9.4 & 0.52 & 0.48 \\
\hline Nuziveedu & $30.43(7)$ & $34.78(8)$ & $34.78(8)$ & 2.1 & 0.48 & 0.52 \\
\hline $\begin{array}{l}\text { Hunuman } \\
\text { Junction** }\end{array}$ & $29.03(9)$ & $67.74(21)$ & $3.22(1)$ & 6.3 & 0.63 & 0.37 \\
\hline Gannavaram** & $23.33(14)$ & $66.67(40)$ & $10.0(6)$ & 7.7 & 0.57 & 0.43 \\
\hline Gudiwada* & $31.82(7)$ & $68.18(15)$ & 0 & 5.8 & 0.66 & 0.34 \\
\hline Machilipatnam & $18.52(5)$ & $51.85(14)$ & $29.63(8)$ & 0.07 & 0.44 & 0.56 \\
\hline Overall** & $21.24(48)$ & $64.60(146)$ & $14.16(32)$ & 20.14 & 0.54 & 0.46 \\
\hline
\end{tabular}

** Significant, $\mathrm{P}<0.01$, ${ }^{*}$ Significant, $\mathrm{P}<0.05$, Values in parenthesis are the numbers of individuals

The genotyping results with regard to codon 200 of the $\beta$-tubulin isotype 1 gene of individual $H$. contortus collected from different regions of Krishna district are presented in the Table 1. Except for the worm populations collected from Nuziveedu and Machilipatnam, the genotype frequencies were not in accordance with the Hardy-Weinberg equilibrium. The frequency of resistant genotypes varied from 6.25 to 31.82 per cent in the district. The frequencies of BZ resistant genotypes were less in Ibrahimpatnam, Nuziveedu and Machilipatnam areas, but the difference was only significant in Ibrahimpatnam $(\mathrm{P}<0.01)$. In those areas where the resistant genotype frequency was higher, the differences were observed to be statistically significant $(\mathrm{P}<0.01)$. None of the worms collected from Gudiwada region were homozygous susceptible.

The overall genotype frequencies varied significantly $(\mathrm{P}<0.01)$ with a high frequency of ' $r S$ ' (64.60\%) genotypes compared to that of ' $\mathrm{rr}$ ' (21.24\%) and 'SS' (14.16\%) genoytpes. With regard to allelic frequency at codon 200, the frequency of the BZ resistant allele ' $r$ ' was found to be significantly $(\mathrm{P}<0.01)$ higher $(54.0 \%)$ as compared to the $\mathrm{BZ}$ susceptible allele ' $\mathrm{S}$ '. F-statistics analysis revealed that the $\mathrm{F}_{\mathrm{IS}}$ and $\mathrm{F}_{\mathrm{ST}}$ values were -0.33 and 0.02 respectively at the 200 codon.

$\beta$-tubulin isotype 1 gene/SnaBI polymorphism in $H$. contortus in sheep. On digestion of the PCR product with SnaBI all 226 samples were found to yield an uncut $488 \mathrm{bp}$ fragment (Fig. 3), as there was no recognition site within the amplified sequence. All the worms which were monomorphic at codon 167 revealed susceptible alleles 'TTC/TTC' and no resistant alleles (TAC) were evident. F-statistics could not be performed at codon 167 as all the worms are monomorphic. 


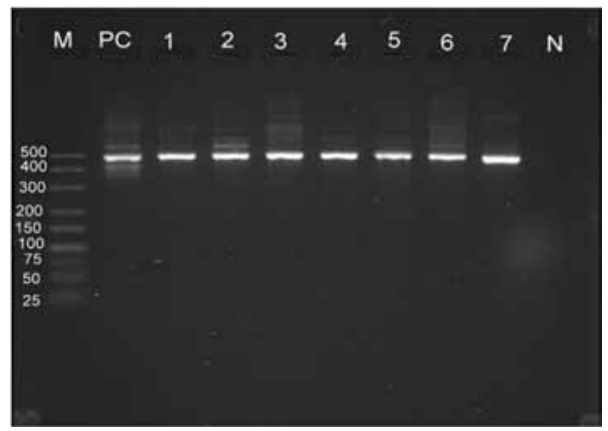

Fig. 3. RFLP Pattern of ß-tubulin isotype1 gene/SnaB1 in H. contortus. M: 25 bp ladder, PC: Positive control, N: Negative control, Lane 1-7: Monomorphic pattern of different worms.

\section{Discussion}

The significant association between the SNPs at codon 167, 198 and 200 of the $\beta$-tubulin gene in conferring $\mathrm{BZ}$ resistance in $H$. contortus has been experimentally evidenced for a decade, and these mutations can be used as diagnostic tags to detect $\mathrm{BZ}$ resistance in $H$. contortus. The perusal of literature revealed isolated reports on the significance of SNP at codon 167 of the $\beta$-tubulin isotype 1 gene in $H$. contortus, particularly from India. In the present study, RFLP analysis of the $\beta$-tubulin gene in $H$. contortus revealed polymorphism at codon 200 and the absence of polymorphism at codon 167, agreeing with the report by SILVESTRE and HUMBERT (2002), where the presence of one SNP is not usually accompanied by a second. The polymorphism at codon 200 is the most frequent mutation conferring BZ resistance in $H$. contortus in small ruminants, and mutations at codon 167 have been observed to occur rarely in the field (SILVESTRE and CABARET, 2002), although this is the frequent and primary mutation in cyathostomins (HODGKINSON et al., 2008). Recent analysis of SNPs in H. contortus populations in Ceará State, Brazil by SANTOS et al. (2017) revealed a higher frequency of resistant allele at SNP F167Y than those at F200Y. Resistant allele were not observed at codon 167 even in the worms that carried susceptible genotypes at codon 200, indicating that mutations at this codon are not common and thus do not contribute to BZ resistance in the study area. However, HODGKINSON et al. (2008) observed heterozygous genotypes at codon 167 and 200 in cyathostomins, and hypothesized that if mutations in the two alleles appeared at both codons in a parasite a stronger level of resistance would develop, leading to death. Further, CHAUDARY et al. (2015) reported the absence of SNP at both F167Y and F200Y in the $\beta$-tubulin isotype 1 gene of $H$. contortus collected from two sheep in one of the locations of the present study (Vijayawada), in order to establish the phylogenetic relationships of the gene. 
Following the reports of HERLICH et al. (1981) and KWA et al. (1995), the heterozygotes in the present study were considered as susceptible since the resistant allele is recessive. The genotype frequencies of $\mathrm{rr}, \mathrm{rS}$ and $\mathrm{SS}$ varied significantly $(\mathrm{P}<0.01)$ in the study area, with a high frequency of BZ susceptible genotypes of $H$. contortus (78.76\%) worms ('SS' and ' $r S$ ') carrying the TTC allele. Moreover, only homozygous ('rr') genotypes appeared to survive with the recommended dose of treatment (ELARD et al., 1999; HUMBERT et al., 2001). In contrast, TIWARI et al. (2006) reported the high frequency of resistant genotypes in $H$. contortus collected from different regions of Rajasthan, considering ' $\mathrm{rS}$ ' as resistant genotypes.

The high frequency of susceptible genotypes in the present study might be due to the following reasons: The Krishna district is a region in Andhra Pradesh where agricultural practices are actively followed such as the practice of letting the sheep flock onto harvested fields. The practice of deep ploughing in the fields at regular intervals exposes the larvae to extreme environmental conditions which are adverse for continuation of infective stages and the perpetuation of parasites, resulting in low levels of infection and hence, low use of $\mathrm{BZ}$ and less selection pressure on resistant population of $H$. contortus. In addition, the practice of annual deworming and use of macrocyclic lactones and imidazothiazoles as alternatives to BZ in sheep could have caused the low incidence of BZ resistance in the flocks. Another possibility could be the parasite collection in summer and winter seasons, when treatment strategies are not practiced routinely. SINGH et al. (1999) opined that the incidence of resistance in parasites could be greater in those collected during the monsoon season when drenching practices in the flocks are highest.

The possibility of a high prevalence $(64.60 \%)$ of ' $r S$ ' individuals might be due to the presence of the recessive allele ' $r$ ' at moderate frequency which results in more heterozygotes due to random mating. Another reason could be the use of under or over dosing of anthelmintics. A sub-therapeutic dose allows the survival of heterozygous worms (EGERTON et al., 1988) and was considered a crucial factor for the further development of resistant strains (SILVESTRE et al., 2001). Correspondingly, the increasing dosage of $\mathrm{BZ}$ reduced the ' $\mathrm{SS}$ ' individuals and increased the TAC allele frequency, thereby increasing the number of ' $r S$ ' and ' $r r$ ' individuals in cyathostomes (PAPE et al., 2003). In accordance with the present findings, the frequency of ' $\mathrm{rS}$ ' genotypes was high compared to that of 'rr' and 'SS' types in H. contortus in goats in Madhura district, India (KAUSHIK et al., 2016).

Although there were more overall susceptible genotypes in $H$. contortus of sheep in the study area, the resistant allelic frequency is significantly high $(\mathrm{P}<0.01)$ due to the presence of a higher number of heterozygotes in $H$. contortus as they harbor both the alleles. In contrast, a high frequency of susceptible allele in $H$. contortus populations in sheep was reported by AMRUTHA (2015) elsewhere in the state. Resistant allele at 
codon 200 on the $\beta$-tubulin gene in $H$. contortus of sheep in a moderate frequency and with a high percentage of heterozygotes in the study area warrants periodic investigations for the early detection of mutated alleles in nematode populations, since reversal to susceptible is not possible even using different anthelmintic molecules with no crossresistance (LEIGNEL et al., 2010).

In conclusion, the present study supported the hypothesis that SNP at codon 200 of the $\beta$-tubulin isotype 1 gene is important in conferring $\mathrm{BZ}$ resistance in trichostrongylid nematodes, and another SNP at codon 167 of the $\beta$-tubulin gene is infrequent. Further periodical screening for resistant allele frequency is warranted to revisit deworming policies.

\section{Acknowledgements}

The authors are thankful to Sri Venkateswara Veterinary University, Tirupati, India, for providing the facilities to do the research work.

\section{Conflicts of interest}

The authors declare that the research was conducted in the absence of any commercial relationships that could be construed as a potential conflict of interest.

\section{References}

AMRUTHA, D. (2015): Study of $\beta$-tubulin gene polymorphism in Haemonchus contortus isolated from Sheep in Rayalaseema region in Andhra Pradesh using PCR-RFLP. MVSc Thesis, Sri Venkateswara Veterinary University, Tirupati, Andhra Pradesh.

CHAUDHRY, U., E. M. REDMAN, M. RAMAN, J. S. GILLEARD (2015): Genetic evidence for the spread of a benzimidazole resistance mutation across southern India from a single origin in the parasitic nematode Haemonchus contortus. International J. Parasitol. 45, 721-728.

EGERTON, J. R., D. SUHAYDA, C. H. EARY (1988): Laboratory selection of Haemonchus contortus for resistance to ivermectin. J. Parasitol. 74, 614-617.

ELARD, L. J., CABARET, J. F. HUMBERT (1999): PCR diagnosis of benzimidazole susceptibility or resistance in natural populations of the small ruminant parasite, Teladorsagia circumcinta. Vet. Parasitol. 80, 231-237.

FALCONER, D. S., T. F. C. MACKAY (2009): Introduction to Quantitative Genetics. $4^{\text {th }}$ ed. Pearson Education Ltd, United Kingdom.

HERLICH, H., R. S. REW, M. L. COLGLAZIER (1981): Heredity of resistance to cambendazole in Haemonchus contortus is probably a result of a heterozygous recessive allele. American J. Vet. Res. 42, 1342-1344. 
K. Sathish et al.: Variation in $\beta$-tubulin gene at codon 167 and 200 of Haemonchus contortus

HODGKINSON, J. E., H. J. CLARK, R. M. KAPLAN, S. L. LAKE, J. B. MATTHEWS (2008): The role of polymorphisms at $\beta$-tubulin isotype 1 codons 167 and 200 in benzimidazole resistance in cyathostomins. International J. Parasitol. 38, 1149-1160.

HUMBERT, J. F., J. CABARET, L. ELARD, V. LEIGNEL, A. SILVESTRE (2001): Molecular approaches to studying benzimidazole resistance in trichostrongylid nematode parasites of small ruminants. Vet. Parasitol. 101, 405-414.

KAUSHIK, R., P. K. ROUT, D. K. SHARMA, S. PAUL (2016): Molecular characterization of beta-tubulin isotype gene of Haemonchus contortus in goats with focus on benzimidazole resistance. Anim. Sci. Report, 10, 48-54.

KWA, M. S., J. G. VEENSTRA, M. D. DIJK, M. H. ROOS (1995): $\beta$-tubulin genes from the parasite nematode Haemonchus contortus modulate drug resistance in Caenorhabditis elegans. J. Mol. Biol. 246, 500-510.

LEIGNEL, V., A. SILVESTRE, J. F. HUMBERT, J. CABARET (2010): Alternation of anthelmintic treatments: a molecular evaluation for benzimidazole resistance in nematodes. Vet. Parasitol. 172, 80-88.

LE JAMBRE, L. F. (1985): Genetic aspects of anthelmintic resistance in nematodes. In: Resistance in Nematodes to Anthelmintic Drugs (Anderson, N., P. J. Waller, Eds.) CSIRO Division of Animal Health and Australian Wool Corporation, Glebe NSW, pp. 97-106.

MARTIN, P. J., N. ANDERSON, R. J. JARRETT (1989): Detecting benzimidazole resistance with faecal egg count reduction test and in vitro assays. Australian Vet. J. 66, 236-240.

PAPE, M., J. POSEDI, K. FAILING, T. SCHNIEDER, G. SAMSON-HIMMELSTJERNA (2003): Analysis of the beta-tubulin codon 200 genotype distribution in a benzimidazole susceptible and resistant cyathostome population. Parasitol. 127, 53-59.

SANTOS, J. M. L., J. P. MONTEIRO, W. L. C. RIBEIRO, I. T. F. MACEDO, J. V. FILHOA, DE ARAÚJO, W. P. P. ANDREA, P. R. M. ARAÚJOC, J. F. VASCONCELOSD, E. P. DE FREITAS D, CAMURC, A. L. A-VASCONCELOS, L. S. VIEIRAB, C. M. L. BEVILAQUA (2017): High levels of benzimidazole resistance and $\beta$-tubulin isotype 1 SNP F167Y in Haemonchus contortus populations from Ceará State, Brazil. Small Rumi. Res. 146, 48-52.

SHOKRANI, H. R., P. SHAYAN, A. ESLAMI, R. NABAVI (2012): Benzimidazole resistance in Haemonchus contortus: New PCR-RFLP method for the detection of point mutation at codon 167 of isotype $1 \beta$-tubulin gene. Iranian J. Parasitol. 7, 41-48.

SILVESTRE, A., J. CABARET (2002): Mutation in position 167 of isotype 1 beta-tubulin gene of trichostrongylid nematodes: role in benzimidazole resistance? Mol. Biochem. Parasitol. 120, 297-300.

SILVESTRE, A., J. CABARET, J. F. HUMBERT (2001): Effect of benzimidazole under-dosing on the resistant allele frequency in Teladorsagia circumcincta (Nematoda). Parasitol. 123, 103-111.

SILVESTRE, A., J. F. HUMBERT (2000): A molecular tool for species identification and benzimidazole resistance diagnosis in larval communities of small ruminant parasites. Exp. Parasitol. 95, 271-276. 
K. Sathish et al.: Variation in $\beta$-tubulin gene at codon 167 and 200 of Haemonchus contortus

SILVESTRE, A., J. F. HUMBERT (2002): Diversity of benzimidazole-resistance alleles in populations of small ruminant parasites. International J. Parasitol. 32, 921-928.

SINGH, D., P. K. SANYAL, C. P. SWARNKAR, F. A. KHAN, P. S. K. BHAGWAN (1999): Influence of diet type and pre-treatment fasting on the disposition kinetics of albendazole in sheep. Vet. Res. Commun. 23, 229-240.

TIWARI, J., S. KUMAR, A. P. KOLTE, C. P. SWARNKAR, D. SINGH, K. M. L. PATHAK (2006): Detection of benzimidazole resistance in Haemonchus contortus using RFLP-PCR technique. Vet. Parasitol. 138, 301-307.

VARSHNEY, T. R., Y. P. SINGH (1976): A note on development of resistance of Haemonchus contortus worms against phenothiazine and thiabendazole in sheep. Indian J. Anim. Sci. 46, 666-668.

WEIR, B. S., C. C. COCKERHAM (1984): Estimating F-statistics for the analysis of population structure. Evolution 38, 1358-1370.

Received: 18 March 2017

Accepted: 3 November 2017

SATHISH, K., C. SREEDEVI, K. SUDHAKAR, P. MALAKONDAIAH, G. S. RAO: Varijacija gena $\beta$-tubulin izotip 1 u kodonu 167 i 200 odgovorna za rezistenciju Haemonchus contortus na benzimidazol iz ovaca uzgajanih u distriktu Krishna, AP, Indija. Vet. arhiv 88, 323-333, 2018.

\section{SAŽETAK}

Provedeno je istraživanje s ciljem otkrivanja polimorfizama pojedinačnih nukleotida u kodonu 167 i 200, $\beta$-tubulin izotip 1 gena koji je povezan s otpornošću ovčjeg parazita Haemonchus contortus prema benzimidazolu (BZ). Genotipizirano je ukupno je 226 odraslih muških crva iz različitih područja distrikta Krishna, Andhra Pradesh. Umnažanje DNA iz svakoga crva pomoću PCR-a praćeno je poluugniježđenim PCR-om, čime je proizveden očekivani fragment od 488 bp. PCR produkt potom je pomiješan s restrikcijskim endonukleazama SnaBI i TaaI radi otkrivanja mutacije u kodonu 167 i 200 . U kodonu 200 opažena su tri različita fragmenta, jedan s 215 bp, 206 bp i 67 bp (homozigotno rezistentan, ,rr“), drugi s 282 bp, 215 bp, 206 bp i 67 bp (heterozigot, „rS“) i treći s 282 bp i 206 bp fragmentom (homozigotno sumnjiv, „SS“). Rezistentni alel (TAC) nije ustanovljen u kodonu 167 svih istraženih crva, uključujući crve koji su nosili sumnjivi alel (TTC) u kodonu 200. Ukupna učestalost genotipova znatno je varirala $(\mathrm{P}<0,01)$ u odnosu na $\beta$-tubulin gen/ TaaI lokus istraženog područja. Učestalost genotipa „rS“ (64,60 \%) bila je visoka u usporedbi s učestalošću genotipova „rr“ i „SS“. Učestalost genotipa „rr“ kod crva iz različitih područja kretala se u rasponu od 6,25 $\%$ do $31,82 \%$. Općenito, opažena je signifikantno $(\mathrm{P}<0,01)$ viša $(54,0 \%)$ prevalencija $\mathrm{BZ}$ rezistentnog alela. Rezultati potvrđuju da polimorfizam kodona 200 u $\beta$-tubulin izotip 1 genu ovčjeg parazita $H$. contortus upućuje na pojavu rezistentnih alela u istraženim područjima.

Ključne riječi: Haemonchus contortus; rezistencija na benzimidazol; polimorfizam gena $\beta$-tubulin; PCR-RFLP 
